\title{
Mediating Role of Good Corporate Governance to Intellectual Capital and Firm Value
}

\author{
Hesti Wahyuni* \\ Accounting Study Program \\ State Polytechnics of Malang \\ Malang, Indonesia \\ *hesti.wahyuni@polinema.ac.id
}

\author{
Erlin Melani, Apit Miharso, Zakiyatul Fuadiyah \\ Accounting Study Program \\ State Polytechnics of Malang \\ Malang, Indonesia
}

\begin{abstract}
Intellectual Capital performance tends to increase the firm value. The effect of intellectual capital to firm value will increase rapidly whenever supported by robust implementation of Good Corporate Governance (GCG). This study is performed to observe mediating effect of GCG to the intellectual capital impact on firm value. From the 48 initial populations, banking institutions listed in Indonesian Stock Exchange, by using purposive sampling method, were selected 29 companies as the samples for the period of 2016-2018. Partial Least Square (PLS) is used to analize the data. This research summarized that intellectual capital had a positive significant effect on Firm Value. This study also proved that GCG components, Audit Comitee and board of directors, has mediating role to the relationship between intellectual capital and firm value as well. Otherwise, independent commisioner and institutional ownership, has no mediating effect.
\end{abstract}

Keywords-component, intellectual capital, good corporate governance, firm value

\section{INTRODUCTION}

The phenomenon of the effect of intellectual capital on organizational performance has been widely discussed throughout the world. Most of the previous studies have proven that intellectual capital has a positive and significant effect on company performance and value. Some research found that intellectual capital has positively signifikan effect to financial performance or organization [1-3]. Otherwise intellectual capital also had positively signifikan effect to firm value. [4], [5]. Subsequent research progress shows that there are variables capable of stimulating the relationship between intellectual capital and company performance or company value, either as a moderator or as a mediator. Some of these variables include good corporate governance [6,7], competitive advantage strategy [1,5], degree of cross-functional organization [2], and corporate social responsibility and several other variables not mentioned in this study.

Non financial or intangible asset are the form of company's assets those related to Intellectual Capital. It is also defined as nonmonetary and nonphysical asset. This Asset are fully or partially controlled by the firm to create customer value and increase the firm value as stated in [1]. Firm value came from the synergy beetwen tangible asset and intangible asset. These synergy are expressed by some indicators of intellectual capital that consist of; human capital, capital employed, structural capital and relational capital [8]. Human capital is the value added in human capability includes motivation, ability to learn, skills, experience, knowledge, core competence, creativeness, and capabilities. The value from capital employed is the number of funds employed as the total amount of capital used for of profits acquisition in whole firm or a project to generate earnings. Capital employed also define as the companies invest in the company long-term future goal, and it must be used with other financial aspect to determine the return on a company's assets as the reflection of the effectiveness in employing capital as management achievement. While, structural capital said as intangibles asset form such as, right, patents, procedures, trademarks, systems, databases, documents, organizational structure, organization culture, qualified information and the effectiveness of the strategy implementation. And the newest indicator is relational capital described as organizational liaison and relationship engage with customer, supplier, distribution channel, networks, alliances, partnerships, government, and stakeholders.

Intellectual capital is a resource developed by an entity as an effort to develop customer value and satisfaction, value for shareholders, and stake holders to increase firm value. Resources Based theory states that the company will have excellent performance and be able to compete in business environment if it can control and use its strategic assets. Strategy can be said to be potential in increasing company performance and company value if it can combine tangible and intangible assets. Company as the owner of resources that can make the company have a competitive advantage, will direct the company to have good long-term performance. Valuable and scarce resources can be directed to create competitive advantage, so that the resources that are owned can last a long time and are not easily copied, transferred and replaced [7].

To maximize the use of resources as an effort to win competition, it is necessary for the company to manage intellectual resources optimally. Optimal management of these resources can only be achieved if the entity has good governance. Good corporate governance as one of the keywords in this study has an important role in the management of an organization's intellectual assets. To 
highlight the importance of Good Corporate Governance role in optimizing company resources untilization, will be discusse briefly in this next part.

Corporate governance is a series of system and prosedur to direct and control the company in carrying out their business activities to achieve their goal. Good corporate governance set a series of systems, prosedures and the strategic ways in doing the business with proper and acceptable manner to get good market performance and also stake holder expectation [9]. In Good Corporate Governance implementation Boards of directors are responsible for the governance in the organization. They should set the company's strategic aims, set the organization structure, set the planning, supervising the strategic business implementation, analize and evaluate the business and arrange the reporting frame work to the shareholders as their stewardship. Otherwise hhe shareholder's role in good corporate governance is to set the prosedur to make sure wether the directors and the auditors on the right ways in achive the goal.

The emphasis of good corporate governance is to make sure the effectiveness of improving process use corporate's tangible and intangible asset to increase company performance. It is related to effective monitoring of internal controls, reliability of financial statements in order to rapidly improves corporate performance. But all of those activities must be done in the ethically and acceptable manner [10]. Ethic and good manner will lead the intellectual capital achieve the excellent corporate value.

In the Indonesian stock exchange-banking sub-sector, good corporate governance plays an important role because banking companies hold the mandate in managing public funds. Public trust in the banking sector is strongly influenced by the behavior of business figures in this sub-sector. The existence of good corporate governance will increase public trust in banking institutions in managing the synergy between physical assets and intellectual assets to increase corporate value.

Prior research also proved that intellectual capital and good corporate governace significantly related to the firms' value [11-13]. It also quoted in prior research that corporate governance blow up the capability and ability to build a bridge to gain outstanding firm value $[11,14,15]$. Reference $[13,14]$ also found that the incremental of intellectual capital role to create good Corporate Governance implemantation. Based on the prior research our research hypothesis stated as:

H1: Intellectual asset has positive impact on company value in the banking sub sector in Indonesian stock exchange

$\mathrm{H} 2$ : intellectual asset has positive impact on good corporate governance inplementation in the banking sub sector in Indonesian stock exchange

H3: Good corporate governance has positive impact on company value in the banking sub sector in Indonesian stock exchange?
H4: Good corporate governance has mediating role on the relationship between intellectual asset and firm value in the banking sub sector in Indonesian stock exchange?

\section{METHODS}

The model developed as the research framework describe in figure 1. This figure explain about the relationship between intellectual capital and firm value and the role of good corporate governance as mediating variable to that relationship. This model shows the direct effect between intellectual capital performance and firm value, intellectual capital performance to good corporate governance, and also the direct effect of good corporate governance to firm value. This research also examine the indirect effect of intellectual capital performance to financial performance through good corporate governance.

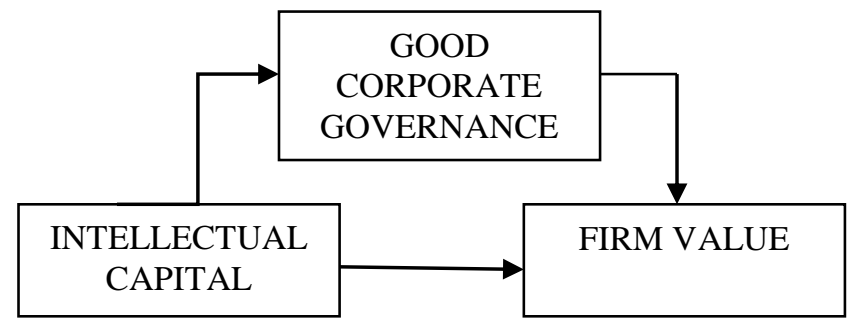

Fig. 1. Research Framework.

\section{A. Population and Samples}

The population that choosen in this research is banking sub sector in Indonesian Stock Exchange. This sector has 90 companies as the population. research samples took from the companies as the member of sector that has highly needed of intellectual capital performance. The purposive sampling method used to select the data. It is is a non-probability sample with certain criteria with previously known population characteristics. The criteria used in this study are presented in table 1 .

TABLE I. SAMPLE SELECTION

\begin{tabular}{|l|l|c|c|}
\hline \multirow{2}{*}{ No } & \multicolumn{1}{|c|}{ Sample Selection Criteria } \\
\cline { 2 - 4 } & \multicolumn{1}{|c|}{ Criteria } & Rejected & $\begin{array}{c}\text { Sample } \\
\text { Selected }\end{array}$ \\
\hline 1 & $\begin{array}{l}\text { All company listed in banking } \\
\text { sub sector }\end{array}$ & 0 & 48 \\
\hline 2 & $\begin{array}{l}\text { Not consistently issued annual } \\
\text { report during 2014 - 2018 }\end{array}$ & 8 & 40 \\
\hline 3 & Suffering loss & 7 & 33 \\
\hline 4 & Not using rupiahs as curency & 3 & 30 \\
\hline 5 & Incomplete data & 1 & 29 \\
\hline & \multicolumn{2}{|c|}{} \\
\hline
\end{tabular}

Source: data processed in 2020

This research use Intellectual Capital as independent variables, Firm Value as dependent variable, and Good Corporate Governance as moderation variables. Independent variable is the variable that is the cause of completion or the impact of the variable received. In this study, the indicators to 
measure intellectual capital (IC) are obtained based on added value created by Employee Capital (EC), Human Capital (HC), and Structural Capital (SC) and Relational Customer (RC). The measurement of intellectual capital in this study uses the concept of added value that was sparked by Siswanti [11]. Added value is an indicator used to assess a company's ability to create value [8]. Value Added is calculated as the difference between output and input [1,2]

The independent variable used is Value Added from intellectual Capital (IC). This value is obtained from the sum of added value components of intellectual capital. The component consists of; EC, HC and SC and RC. Value added is the added value of intellectual capital investment obtained from Output input. Output is derived from total sales revenue and other income, while Input is all expenses other than employee expenses.

$\mathrm{CE}$ is a value added indicator (VA) produced by 1 unit of physical capital employed by a company. The CE ratio shows the comparison between VA and company CE [7]. It means increase of 1 unit of $\mathrm{CE}$ can increase the return, so the entity maximizes its capital utilization. The $\mathrm{CE}$ calculation formula is:

\section{CE = VALUE ADDED / Capital Employed \\ Capital Employed = equity + net income}

Value Added Human Capital (HC) measures the added value of each rupiah used to improve the capability of the workforce. HC illustrates the benefits of each Human Capital investment rupiah and the added value that accompanies it. Employee costs incurred by companies are usually stated in the salary expense account. Total labor costs are an indicator of company [6]. Note: HC (Value Added Human Capital) is measured by the formula:

\section{HC = VALUE ADDED / HUMAN CAPITAL}

Human Capital $=$ employee expenses

Structural Capital Value Added (SC) is an indicator that shows the contribution of structural capital (SC) to creating added value (VA) for companies. In this case, the company's $\mathrm{VA}$ is generated by measuring the amount of structural capital (SC) needed to generate 1 rupiah from the VA and is an indication of how successful the SC is in value creation [6]. SC is the ratio of SC to VA measured by the formula:

\section{SC = STRUCTURAL CAPITAL $/$ VALUE ADDED}

Structural Capital $=$ Value Added - Human Capital

Relational Customer is the relationship between company and their customer. The closer the relationship the more information the company will get from the customer. This information will be used by the company in making continuous improvements to increase value for customers.

\section{RC $=$ RELATIONAL CAPITAL / VALUE ADDED \\ Relational Capital $=$ Marketing Cost}

Dependent Variable employed in this study is firm value that measured by Tobin's $Q$ ratio. Tobin's $Q$ ratio measurement done by sum the market value of the stock with liabilities book value and then divide it with total activa. Tobin's $Q$ ratio represents the investment opportunity owned by the company [16]. Tobin's $Q$ ratio formula is

Tobin's $Q=($ Market Value of Equity + Total Liabilities $) /$ Total Asset [17].

Market Value of Equity: stock closing price $\mathrm{x}$ number of outstanding stock at December 31.

Corporate control carried out by various parties in the company can be achieves through the Good Corporate Governance mechanism. Those mechanism stated in these proxies, by the role of the independent board of commissioners, the board of directors and the audit committee [18]. In addition, there are other factors that can reduce un ethically manner, the proxies are institutional ownership, independent commissioners, audit committee and board of directors [19].

Institutional ownership is the number of company shares owned by institutions or other institutions outside the company [20]. Institutional ownership is believed by some researchers to be able to influence the running of the company which in turn will affect the company's performance in achieving its objectives, namely the maximization of company value. The formula to measure this indicator stated below:

INSOWN = NUMBER OF SHARE OWNED BY INSTITUTION / TOTAL OUTSTANDING SHARE

The independent board of commissioners is a party that is not affiliated with a company, does not have concurrent positions in other companies affiliated with a company, and understands the laws and regulations in the capital market. Public companies are required to have independent commissioners of at least $30 \%$ of all members of the board of commissioners. The proportion of independent commissioners can be calculated by: NUMBER OF INDEPENDET COMMISIONER / TOTAL COMMISIONER MEMBER

The Audit Committee is a committee formed by and responsible to the board of commissioners in helping carry out the duties and functions of the board of commissioners". The audit committee is a committee formed by the board of commissioners which has the duty and responsibility to assist the board of commissioners in conducting internal oversight, ensuring the effectiveness of the internal and external auditors and strengthening the independence of auditors. The audit committee variable is measured by looking at the : NUMBER OF AUDIT COMMITTEE MEMBERS OF THE COMPANY.

Board size or the total member of the board of directors, the more boards in the company will provide a stronger form of oversight of the company's performance. The board of directors is tasked with reviewing management performance to ensure that the company is well run and protects the interests of shareholders. According to Nurhayati [17], the board of directors can encourage management to submit financial statement information according to the actual situation so as to minimize earnings management actions. The board of directors is measured by the : NUMBER OF MEMBERS OF THE BOARD OF DIRECTORS IN THE COMPANY. 


\section{RESULT AND DISCUSSION}

Partial Least Square required two stages in testing models. The first is outer model and the second is inner model. Outer model specifies to the relationship between latent variables and indicators and it defines how each indicator relates to its latent variable. IC has 4 indicators that consist of $\mathrm{CE}, \mathrm{HC}, \mathrm{SC}$ and $\mathrm{RC}$. In formatif form the indicator are assumed have already fulfill this requirement, so the data to be analyzed are convergently valid. The following below is the output in the form of Outer Loading value of each variable for the overall model (table 2).

The requirement value of outer loading test is between the ranges of 0.5 until 1.0. It means all data are valid on a fixation based and can be included in further testing. Then discriminant validity will be tested by looking Average Variance Extracted root value (AVE) for each construct and comparing with correlations between constructs. Discriminant validity test is used to see whether an indicator of a particular latent variable is really different from the indicators of other latent variables, so that the indicator is really considered feasible to explain the latent variable.

TABLE II. OUTER LOADING

\begin{tabular}{|l|c|c|c|c|c|c|}
\hline & \multicolumn{7}{|c|}{ VARIABLES } \\
\hline & $\begin{array}{c}\text { MVA } \\
\text { IC }\end{array}$ & $\begin{array}{c}\text { AUCO } \\
\boldsymbol{M}\end{array}$ & $\boldsymbol{B O D}$ & $\begin{array}{c}\text { INCOM } \\
\boldsymbol{M}\end{array}$ & $\begin{array}{c}\text { INSO } \\
\boldsymbol{W N}\end{array}$ & $\boldsymbol{Q}$ \\
\hline MVAIC & 1,000 & & & & & \\
\hline AUCOM & & 1,000 & & & & \\
\hline BOD & & & 1,000 & & & \\
\hline INCOMM & & & & 1,000 & & \\
\hline INSOWN & & & & & 1,000 & \\
\hline Q & & & & & & 1,000 \\
\hline
\end{tabular}

Source: data processed in 2020

Discriminant validity testing is done by looking at the average variance extracted (AVE), if the AVE value is greater than 0.5, then the indicator data is considered to meet convergent validity. It also can be seen by looking at the coefficient value in the cross-loading table, where the highest coefficient value indicates that the indicator indeed represents the observed variable. All of these variable has 1 as the AVE value and meet the requirement.

From cross loading value requirement, all of indicator are valid to explain the related latent variable. To explain MVAIC, CE has $86,6 \%$, $\mathrm{HC}$ has $83,5 \%$, SC has $90 \%$ and RC has $80,3 \%$. AUCOM has $90,3 \%$, BOD has $100 \%$, INSOWN HAS $78 \%$ and INCOMM has $80,25 \%$ cross loading value to explain GCG. Cross-loading describe the correlation of constructs with the indicator data is higher than the correlation of those indicators with other variables. It shows that latent constructs predict indicators in their blocks better than indicators in other blocks. The last step of outer model is Reliability testing. This test is done to make sure that all of variables have reliable enough to predict the hypothesis testing model.

Construct Reliability with Cronbach alpha measuring construct reliability, the value must be above 0.70 which is considered reliable. The value of Cronbach alpha measured in this research to all variables have the perfect value or $100 \%$. It Means Construct Reliability assumption were already met.

The second step of PLS technique is inner model testing. Inner model testing consists of 3 testing. Firstly, is R Square, secondly is direct effect (path coefficient and $p$ value) and the third is indirect effect (path coefficient and $p$ value). Inner model or structural model testing consists of the measurement of R Square value and the value of hypothesis testing result. Rsquare (R2) value for dependent construct reflects the predictive power of the whole model with the limitation on the $\mathrm{R}$-square value greater than 0.10 or greater than 10 percent (or goodness-fit of the model). Based on data

Table 5 presented that Composite reliability is good if the value is above 0.70 . Thus, it can be said that the indicators of CA, FP, VAIC, really reinforce each other's latent variables or really able to measure their latent variables. So, the model in this study has met the composite reliability. Construct reliability based on Cronbach's alpha is good if the value is above 0.70. Based on the above table, all observed variables Cronbach's alpha are above 0.70. It means the model in this study has fulfilled Construct reliability requirement. The second step of PLS technique is inner model testing. Inner model testing consists of 3 testing. Firstly, is R Square testing, secondly is direct effect (path coefficient and $p$ value) and the third is indirect effect (path coefficient and $p$ value).

Inner model or structural model testing consist of the measurement of $\mathrm{R}$ Square value and the value of hypothesis testing result. R-square (R2) value for dependent construct reflects the predictive power of the whole model with the limitation on the $\mathrm{R}$-square value greater than 0.10 or greater than 10 percent (or goodness-fit of the model). Based on data processing by PLS, the coefficient of determination (R-square) is produced. R-square value for GCG as mediating variable are $46,7 \%$ for AUCOM, $17 \%$ for BOD, $10 \%$ for INCOMM and $0.7 \%$ for INSOWN. The conclusion is both of AUCOM and BOD met the requirement, but neither of INCOMM and INSOWN. Hypothesis testing and the direct relationship between variables can be seen from the results of the path coefficient on the model, here are the results of the path coefficient on the inner model in table 3.

TABLE III. PATH COEFICIENT

\begin{tabular}{|l|l|l|l|l|}
\hline & \multicolumn{1}{|c|}{$\mathbf{M}$} & $\begin{array}{c}\text { STDE } \\
\mathbf{V}\end{array}$ & $\begin{array}{c}\text { O/STDE } \\
\mathbf{V}\end{array}$ & P VALUES \\
\hline Aucomm -> Q & $-0,187$ & $-0,209$ & 0,107 & 0,081 \\
\hline bod -> Q & $-0,077$ & $-0,054$ & 0,142 & 0,589 \\
\hline incomm -> Q & 0,022 & 0,063 & 0,136 & 0,869 \\
\hline insown -> Q & $-0,004$ & 0,008 & 0,057 & 0,942 \\
\hline vaic -> Aucomm & $-0,168$ & $-0,159$ & 0,082 & 0,040 \\
\hline vaic -> Q & 0,245 & 0,276 & 0,084 & 0,004 \\
\hline vaic -> bod & 0,522 & 0,527 & 0,061 & 0,000 \\
\hline vaic -> incomm & $-0,090$ & $-0,096$ & 0,089 & 0,312 \\
\hline vaic -> insown & $-0,037$ & $-0,060$ & 0,079 & 0,636 \\
\hline
\end{tabular}

Source: data processed in 2020 
From table 3 direct effect from Intellectual Capital to firm value, Intellectual Capital to Audit Comitee and Intellectual Capital to Board of Directors are positively significant, and the others direct effects are not significant. Significant effect proved by the value of $T$ statistic is higher than 2 and $P$ value is lower than 0.05 . other effect is indirect effect explained by the relation between Intellectual capital and Financial Performance through Competitive Advantage. Significant effect is detected with the t- stat value that higher than 2 . Another way to detect significant effect is $\mathrm{p}$-value must be lower than 0.05 . $\mathrm{P}$ value number 0.902 is greater than 0.05 indicate that all of CGC component has no significant effect to this relation.

Intellectual capital role to create firms' value is a predictor in the emerging market context [14]. It also happened in Banking sub sector. Prior reseachs also found positive effect to good and effective resources utilization [8,10,13]. Effective utilization earn incremental profit in every resources spent. Intellectual capital that consist of smart people, smart technology, qualified information and efficient procedure and system. If those excellences were blended, it will creates excellent financial performance.

Some previous research found that IC and performance has interaction effects in many industry sectors $[10,15,16]$. Prior researchers also agree that intellectual property right has significant relation to the firms' value $[1,2,5]$. It is also found that in banks sector, firm value relation with human capital efficiency than physical capital efficiency and is higher than structural capital efficiency [14]. The more cost spent in intellectual capital should be continued by stake holder value creation and positive impact to firm value. There some ways to create firm value. Firstly, Investment in intellectual asset will increase the level of productivity, effectiveness and efficient of resources utilization to creat value. Second, intellectual capital used in research and development program to create new customer value of company products or services. So, it can be concluded that intellectual capital has positive effect to financial performance and the result of this research is at the same manner.

This study has successfully proves that intellectual has significant effect to firm value. This research also proves that intellectual has significant effect to audit comitee and board of directors. Otherwise there are no significant effect of intellectual capital to independent commisioner and institusional ownership. Mediating effect also failed to be proved in this study.

About the significant effect of intellectual capital to the firm value has been discussed in many research. No doubt to this statement. The development of intellectual capital research has spread to the interaction effect of this relationships. Good corporate governance component has potential effect to have some mediating variable in this case. And the effect of these each aspect will be discuss in the next paragraph.

ISA 200 stated about General Objectives and Principles of Financial Reporting Governance aims: The objective of an audit of financial statements is to activate the auditor to express an opinion on whether the financial statements are, in all material respects, consistent with those applicable in the financial reporting framework. Agree to the Terms of the Engagement As specified in ISA 210, "Audit Engagement Requirements": Document appointment letter and auditor's appointment, the purpose and scope of the audit, the extent of the auditor's responsibility to the client and the form of each report. Factors that affect the auditor's judgment in conducting the engagement: (1) The need for sufficient expertise in banking aspects relevant to audit of bank business activities. (2) The need for expertise in the context of IT systems and communication networks using the bank. (3) Adequacy of resources or inter-company arrangements to carry out work is required at a number of domestic and international locations where audit procedures are required. From this statement we can conclude that intellectual capital that called as expertise really needed to achieve the audit succesful.

Further discussion, the use and sources of specific accounting principles, with reference to: Any requirements contained in applicable laws or regulations to the bank; Issuance of Standards for supervisory and regulatory oversight; Issuance of relevant standards of professional accounting bodies, for example, the International Accounting Standards Board; Statement from the Basel Committee on Banking Supervision, and Industrial Practice. The content and form of the auditor's report on the financial statements and any specific purpose reports required of the financial statement auditors. The nature of any special communication needs or protocols that may exist between auditors and supervisors of banking and other government regulations. Supervisory access that the bank will be granted to paper auditors work when such access is required by law, and advance the bank's approval for this access.

Bank shareholders should exercise their right to vote members of the Board of Commissioners and Directors with high integrity and able to manage and control a bank in a healthy manner. This integrity and ability only be obtained by intellectual capital. The working relationship of the Board of Commissioners and the Board of Directors is a check relationship and balances with the ultimate goal of advancement and health of the bank. Therefore hhe Board of Commissioners and Directors, according to their respective functions, have the responsibility to maintain business continuity bank in the long term as reflected in maintaining the health of the bank in accordance with the principle of prudence and criteria stipulated by the Bank Supervisory Authority, Good implementation of internal control (internal control) and risk management, Achieving reasonable returns for shareholders, Protected interests of stakeholders fairly, Fulfillment of GCG implementation and The implementation of leadership succession and management continuity across all lines of the organization.

Based on the statement discussed above, the board of commissioners and board of directors should be closely related to intellectual capital. However, the results of this study indicate that only the board of directors is affected by 
intellectual capital. The possible cause of this condition is the lack of role of the independent board of commissioners in the operations of banking companies. So that it is less of a point of concern for the allocation of intellectual assets of banking companies.

\section{CONCLUSION}

The significant effect of intellectual capital to the firm value was found in this study. This result also has been confirmed and discussed in many research. This study has succeeded in confirming the intellectual capital support that is very much needed in the audit process, both internal and external audits. Quality human resources, management expertise, and an integrated system are essential in improving the smoothness and success of the audit program.

Board of commissioners and board of directors should be closely related to intellectual capital. However, the results of this study indicate that only the board of directors is affected by intellectual capital. The possible cause of this condition is the lack of role of the independent board of commissioners in the operations of banking companies. So that it is less of a point of concern for the allocation of intellectual assets of banking companies.

\section{REFERENCES}

[1] H. Wahyuni, "Pengungkapan Paradigma Lintas Fungsional Sebagai Pemediasi Hubungan Modal Intelektual dan Kinerja Organisasi”. Jurnal Riset dan Aplikasi: Akuntansi dan Manajemen, 4(1). 2019

[2] H. Wahyuni, E. Melani, \& T. Candrawati, "Competitive Advantage as a Mediating Variable to the Relationship Between Intellectual Capital and Financial Performance". In 1st Annual Management, Business and Economic Conference (AMBEC 2019) (pp. 69-74). Atlantis Press. April 2020

[3] S. Suroso, T. Widyastuti, M.N. Salim, \& I. Setyawati, "Intellectual capital and corporate governance in financial performance Indonesia Islamic banking". International Journal of Economics and Financial Issues, 7(4). 2017.

[4] B.S. Bambang \& M. Mukhtaruddin, "Intellectual capital, firm value and ownership structure as moderating variable: Empirical study on banking listed in Indonesia Stock exchange period 2009-2012”. Asian Social Science, 11(16), 1-12. 2015

[5] Z. Fuadiyah, "Pengaruh Intellectual Capital terhadap Nilai Perusahaan dengan Kinerja Keuangan dan Keunggulan Kompetitif sebagai Variabel Mediasi pada Perusahaan Sektor Keuangan yang Terdaftar di Bursa Efek Indonesia." unpublished

[6] A.M. Hamdan, A.M., Buallay \& B.A. Alareeni, "The moderating role of corporate governance on the relationship between intellectual capital efficiency and firm's performance: evidence from Saudi Arabia". International Journal of Learning and Intellectual Capital, 14(4), 295-318. 2017.
[7] J.H. Tsai \& S.Y. Wen, "Intellectual capital, corporate governance and firm performance". Information Management and Business Review, 5(10), 482-491. 2013.

[8] I. Ulum, R. Rizqiyah, A.W. Jati, "Intellectual capital performance: A comparative study between financial and non-financial industry of Indonesian biggest companies". International Journal of Economics and Financial Issues, 2016, 6.4: 1436-1439. 2014

[9] M. Rodriguez-Fernandez, "Social responsibility and financial performance: The role of good corporate governance". BRQ Business Research Quarterly, 2016, 19.2: 137-151.

[10] N. Kamukama, A. Ahiauzu \& J.M. Ntayi, "Competitive advantage: mediator of intellectual capital and performance". Journal of intellectual capital. 2011

[11] I. Siswanti, et al., "The impact of Islamic corporate governance, Islamic intellectual capital and Islamic financial performance on sustainable business Islamic banks". International Journal of Economics and Financial Issues, 7.4. 2017

[12] M.C. Wang, "Value relevance on intellectual capital valuation methods: the role of corporate governance". Quality \& Quantity, 47.2: 1213-1223. 2013.

[13] J. Arifin, "Corporate Governance and Intellectual Capital on Firm Value of Banking Sector Companies Listed at Indonesia Stock Exchange in Period 2008-2012". WACANA, Jurnal Sosial dan Humaniora, 20(1) 2017 ,

[14] M. Iranmahd, M. Moeinaddin, N. Shahmoradi \& F. Heyrani, "The effect of intellectual capital on cost of finance and firm value". International Journal of Academic Research in Accounting, Finance and Management Sciences, 4(2), 1-8. 2014.

[15] S.E. Hatane, A.T. Djajadi, J. Tarigan, "The impact of corporate governance on intellectual capital and firm value: Evidence from Indonesia and Malaysia consumer goods". PhD Thesis. Petra Christian University. 2017.

[16] S.W. Putri \& N.F. Nuzula, "Pengaruh Intellectual Capital terhadap Kinerja Keuangan dan Nilai Perusahaan (Studi pada Perusahaan Sektor Manufaktur yang terdaftar di Bursa Efek Indonesia Periode 20122017)". Jurnal Administrasi Bisnis (JAB)|Vol. 66 No. 1 Januari 2019. https://administrasibisnis.studentjournal.ub.ac.id 2019.

[17] S. Nurhayati, "Analisa Pengaruh Intellectual Capital Terhadap Kinerja Pasar Dan Kinerja Keuangan Pada Perusahaan LQ45 Yang Terdaftar D Bursa Efek Indonesia Periode Tahun 2010-2013". Jurnal Akuntansi Riset. Program Studi Akuntansi. Fakultas Pendidikan Ekonomi dan Bisnis Universitas Pendidikan Indonesia, 9 (1), 133-172. 2017.

[18] C. Taco and V. Ilat, "Pengaruh Earning Power, Komisaris Independen, Dewan Direksi, Komite Audit, dan Ukuran Perusahaan Terhadap Manajemen Laba". Jurnal EMBA Universitas Sam Ratulangi Manado. Vol.4, No.2, 873-884. 2016

[19] W.I. Arwindo, "Analisis Pengaruh Kepemilikan Institusional, Leverage, Ukuran Perusahaan dan Profitabilitas terhadap Manajemen Laba Stud pada Perusahaan Manufaktur yang Terdaftar di BEI 2009-2014". Skripsi. Semarang. Fakultas Ekonomi dan Bisnis. Universitas Diponegoro. 2013.

[20] Y. Junchristianti, "Pengaruh Mekanisme Corporate Governance Terhadap Hubungan Antara Manajemen Laba Dengan Nilai Perusahaan”. Jurnal Ilmu dan Riset Akuntansi, 4(3), 1-25 2015. 